\title{
MANCHESTER
}

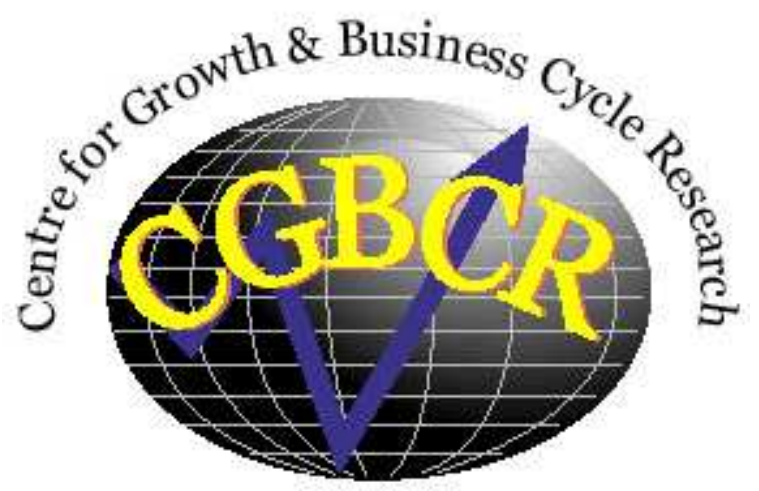

Discussion Paper Series

\section{Financial Dollarization and European Union Membership \\ By}

\section{Kyriakos C. Neanidis}

Centre for Growth and Business Cycle Research, Economic Studies,

University of Manchester, Manchester, M13 9PL, UK

June 2010

Number 143

Download paper from:

http://www.socialsciences.manchester.ac.uk/cgbcr/discussionpape rs/index.html 


\title{
Financial Dollarization and European Union Membership
}

\author{
Kyriakos C. Neanidis \\ Economics, University of Manchester and Centre for Growth and Business Cycle Research \\ Manchester M13 9PL, United Kingdom
}

\begin{abstract}
We analyze the effect of European Union (EU) membership on financial dollarization for the Central and Eastern European countries. Using a unique monthly dataset that spans about two decades, we find that both the accession process toward EU membership and EU entry have a direct impact on deposit and loan dollarization. EU membership reduces deposit dollarization while it increases loan dollarization. The negative effect on deposit dollarization captures the increased confidence of the private sector in the domestic currency as they consider the EU admission process to reflect their government's commitment in promoting policies of long-run currency stability. The positive impact on credit dollarization is the outcome of a greater convergence of exchange rates to the euro and the subsequent anticipation for a lower currency risk, which diminishes the cost of foreign currency borrowing.
\end{abstract}

Keywords: Financial dollarization; European Union membership; Accession process

JEL Classification: E44; F31; G11; G20

\section{Introduction}

Does the prospect of European Union (EU) membership affect the level of financial dollarization (FD)? If so, toward which direction, and does the effect differ between deposit (DD) and loan dollarization (LD) $?^{1}$ These questions are important as two decades of research on the subject of FD have unveiled its significance as a potential source of financial crises and macroeconomic instability, especially in the event of sudden exchange rate fluctuations. Given our incomplete understanding of the ingredients that influence FD and in particular the potential role of EU membership, this paper examines the determinants of DD and LD in Central and Eastern Europe (CEE) by focusing on the impact of both the transition process toward EU accession and of the eventual membership itself.

\footnotetext{
${ }^{1}$ Financial dollarization refers to deposits and loans in foreign currencies and not just in dollars. In particular, and in line with the literature, DD reflects the ratio of foreign currency deposits to total deposits of residents at domestic banks, while LD refers to the ratio of foreign currency loans to total loans of domestic banks to residents.
} 
Even though the FD literature has a long history with regard to the investigation of its drivers, the potential influence of EU membership has only recently attracted the attention of researchers, the consideration of which has offered mixed results. On the one hand, Genberg (2004), Levy-Yeyati (2006), and Rosenberg and Tirpák (2008) offer the view that EU membership by leading eventually to euro adoption triggers higher FD in anticipation of admission to the Economic and Monetary Union (EMU). The mechanism of this positive channel is expressed by the higher trade and financial transactions with the EU, a greater convergence of exchange rates to the euro, a growing acceptance of the euro as a store of value, the higher degree of borrowing in foreign currency in the expectation of diminishing currency risk, and full access to foreign currency holdings as the prospective EU members will have to lift their restrictions on capital mobility.

The negative impact of joining the EU on FD, on the other hand, is depicted by Levy-Yeyati (2006), Honig (2009) and the related institutional view (De Nicoló et al., 2003, 2005). According to this view, a credible government (of high institutional quality) by following policies that promote long-run currency stability can build up its reputation and encourage confidence in the domestic currency. Joining the EU lends credibility to the policymakers of the candidate or acceded country as they are perceived in the eyes of the private sector to commit to policies that contribute to long-run macroeconomic and, especially, currency stability (Ravenna, 2008). EU admission, therefore, acts as a commitment device to enhance institutional quality, thereby promoting faith in the local currency.

Given the conflicting views expressed on this matter, we test the significance of joining the EU on FD, while controlling for the most important drivers found in the literature. Our empirical evidence shows that EU membership does influence FD. In particular, we find that all three stages of the accession process play a significant role on FD. That is, not only EU membership per se matters, but also the transition process toward joining the EU as this is captured by the official dates of the beginning of the process of membership negotiations and of the decision by the EU to allow candidate countries to join the Union (the conclusion of accession negotiations). As it concerns DD, both the transition period and eventual EU membership induce a decline, which increases in absolute magnitude across the three stages of accession as countries reach EU admission. This result provides support to the institutional-credibility view which may reflect the credibility effect of EU accession as domestic depositors consider this process to reflect their government's commitment in promoting policies of long-run currency stability, as these are necessary requirements toward final admission (Ecofin, 2000). We find this effect to be robust to the inclusion of an indicator of institutional quality suggesting that EU admission has a complementary effect on DD above 
and beyond the effect exerted by the credibility of monetary and government policies through higher government quality.

Interestingly enough, our results also indicate that EU membership, along with the two preadmission stages, leads to a contrasting effect on LD as borrowing in foreign currency rises. As in the case of DD, the absolute size of this effect increases as a country progresses from one stage of the process to the next. This finding suggests that lenders and borrowers of foreign currency view EU admission as a channel for higher convergence with the EU member states in both trade and financial links. This may also reflect their increased confidence in the policies of their national governments as holdings of foreign currency become less risky, especially in the expectation of euro adoption. Overall, the opportunity of more profitable transactions with the co-member states and the lower risk of foreign currency holdings encourage LD. This result continues to hold even when we explicitly control for an indicator of institutional quality.

In general, these findings illustrate that foreign currency deposits and foreign currency loans respond asymmetrically to the prospect of EU admission. They, therefore, offer support to the joint consideration of both sides of the bank's balance sheets when it comes to the analysis of financial dollarization. It is worth mentioning that all our findings are insensitive to a battery of tests, such as the use of alternative estimation techniques, instrumentation strategies, regression specifications, and consideration of country and period outliers.

The remainder of the paper is organised as follows. Section 2 describes the estimation strategy and the dataset. Section 3 reports the findings of the analysis, while Section 4 concludes.

\section{Methodology and data}

We follow the existing literature in choosing the potential drivers of FD to which we add three dummy variables that relate to the EU membership process. These are dummies that signify the periods of the beginning of the negotiation process (stage 1), the completion of the negotiation process at which the EU has decided for negotiating countries to join the EU (stage 2), and the date after which full membership is granted (stage 3$)^{2}$ As we examine independently the determinants of DD and LD, the benchmark regression specifications we use are

\footnotetext{
${ }^{2}$ These dates appear in the Appendix, Table A1 and can be found at the official EU website: http://europa.eu/abc/history.
} 


$$
\begin{aligned}
& D D_{i t}=\alpha_{0}+\sum_{j=1}^{m} \beta_{j} X_{j, i t}+\sum_{l=1}^{n} \gamma_{l} D_{l, i t}+\sum_{k=1}^{3} \delta_{k} E U_{k, i t}+\varepsilon_{i t}, \\
& L D_{i t}=\alpha_{0}+\alpha_{1} D D_{i t}+\alpha_{2} n f a_{i t}+\sum_{j=1}^{m} \beta_{j} X_{j, i t}+\sum_{l=1}^{n} \gamma_{l} D_{l, i t}+\sum_{k=1}^{3} \delta_{k} E U_{k, i t}+u_{i t} .
\end{aligned}
$$

$D D_{i t}\left(L D_{i t}\right)$ denotes DD (LD) in country $i$ at time $t, n f a$ stands for banks' net foreign assets, while $X_{j}$ represents a set of conditioning variables that are commonly found to influence both DD and LD. ${ }^{3}$ These are the rate of inflation according to the currency substitution view (Savastano, 1996), the minimum variance portfolio (mvp) dollarization share according to the portfolio view (Ize and Levy-Yeyati, 2003), the rate of depreciation to control for valuation effects in the measures of dollarization (Arteta, 2005), the interest rate differential to test the departure from uncovered interest rate parity (Basso et al., 2007), and an indicator of international financial integration (Lane and Milesi-Ferretti, 2007) as a measure of financial openness (Luca and Petrova, 2008; Honig, 2009; Neanidis and Savva, 2009). ${ }^{4}$

To briefly explain the expected influence of these variables on FD note that Barajas and Morales (2003), Luca and Petrova (2008), and Neanidis and Savva (2009) have shown banks to limit their exchange rate risk by lending in foreign currency as they receive more foreign currency deposits suggesting the positive effect of DD on LD in equation (2). They also show that banks prefer to match the level of overall assets and liabilities by currency, so that they channel foreign currency deposits to the purchase of foreign assets. In this way, an increase in $n f a$, for a given level of DD, decreases LD. ${ }^{5}$ High rates of inflation and depreciation by diminishing the value of the domestic currency, are expected to boost FD. Similarly positive is the recorded effect of mvp dollarization as it captures the importance of the volatility of inflation against that of real depreciation. Given that interest rate differentials are defined as local currency minus foreign currency rates, their increase should decrease (increase) DD (LD). Finally, greater financial integration with the rest of the world may raise both foreign currency deposits and credits. As financial

\footnotetext{
${ }^{3}$ Note that equation (2) controls explicitly for the effects of supply side variables on $L D$ that are driven by the behavior of banks as illustrated by $D D$ and $n f a$. This is justified by the findings of Luca and Petrova (2008) and Neanidis and Savva (2009), who show that supply side variables have a robust impact on $L D$ in transition economies.

${ }^{4}$ The institutional view advanced by De Nicolo et al. (2005), Rennhack and Nozaki (2006), and Honig (2009) which supports the notion that improved quality of government institutions reduces FD, is not directly controlled for in our benchmark regressions as including such an index decreases our sample size by a fourth. To consider this important driver, however, we do include it in our extended regressions that appear below. Our results confirm its significance.

${ }^{5}$ An alternative interpretation for the negative impact of banks' net foreign assets on LD is as follows. Given that many transition countries report highly negative net foreign assets of their banking sector (see, for instance, the negative mean value of $n f a$ in Table 1), this represents a reflection of their funding sources from abroad. This external funding source, in turn, limits the need of banks for foreign currency lending. I thank a referee for this interpretation.
} 
openness makes the domestic banking and financial sector more accessible to foreign investors, a greater inflow of foreign currency will be the outcome of higher rates of return on deposits and investment projects. Domestics lenders, on the other hand, may be more willing to extend dollar credit to exporters and importers that require more foreign currency for their businesses, and especially for exporters earning revenue in dollars who are less risky with regard to dollar default.

The set $D_{l}$ includes two dummy variables that control for the regulatory and the high-dollarization environments. These are a dummy that considers the presence of restrictions on holding deposits (loans) in foreign currency based on the IMF's Annual Report on Exchange Arrangements and Exchange Restrictions (Arteta, 2005) and a dummy that controls for occasions of high degrees of dollarization (Neanidis and Savva, 2009). The former dummy is clearly expected to have a negative effect on FD, while the latter has been found to promote FD as it captures the bias of both depositors and lenders in highly dollarized countries to hold more foreign currencies in their portfolios due to higher currency risk. Following Honohan (2007), we first consider as highly dollarized environments those with DD and LD ratios in excess of $50 \%$, although we take proper care in verifying our findings by altering the threshold level to the mean and median (Levy-Yeyati, 2006), at the 40\% level (Rennhack and Nozaki 2006), and at the top quartile (Honohan, 2007).

The main contribution of this paper is illustrated by the set $E U_{k}$ which is defined to include the three EU membership related dummies described above. We include the three dummies separately as each of them may unveil a different or an additional marginal impact of potential EU admission on FD. Their significance will highlight the importance foreign currency market participants attach to the prospect of entering the EU as it concerns their increased confidence in the domestic currency and the growing anticipation of diminishing foreign currency risk. Our focus, therefore, will primarily be directed to the sign and significance of the coefficients $\delta_{k}(k=1,2,3)$. Finally, $\varepsilon_{i t}$ and $u_{i t}$ correspond to the error terms. ${ }^{6}$

A variety of econometric procedures are used to estimate equations (1) and (2). The first is a standard panel regression technique, the Feasible Generalized Least Squares (FGLS) estimator preferred by Basso et al. (2007). The other two estimation procedures are based on techniques that address potential endogeneity of the right-hand-side variables. Our preference for these techniques lies in their consideration for addressing simultaneity bias, which is an obvious issue in these regressions. In line with the literature, we control for the possible endogeneity of inflation, depreciation, mvp dollarization, and interest rate

\footnotetext{
${ }^{6}$ The importance of most of these drivers of FD is well explained in the survey paper of Levy-Yeyati (2006). In addition, Table A2 of our Appendix provides a detailed description of the variables used in the analysis and their respective sources.
} 
differences as potential monetary policy instruments. In addition, we instrument for our indicator of financial openness and, for the case of LD, for DD and banks' net foreign assets. Following the most recent articles in the literature (Luca and Petrova, 2008; Honig, 2009; Neanidis and Savva, 2009), we use as instruments the once lagged values of the potentially endogenous variables. ${ }^{7}$ We also extent the instrument set to the second lag, the third lag, and any combination of these lags for the sake of robustness. The instrumentation techniques we utilize are the fixed and random effects 2SLS estimations with robust standard errors adjusted for heteroskedasticity and serial correlation. ${ }^{8}$

One set of variables we do not instrument for are the three EU-related dummies. This requires that EU membership is not a function of financial dollarization, or of any variable affecting dollarization that is omitted in equations (1) and (2). We are reasonably confident that this condition is met. EU membership is certainly affected by factors like macroeconomic stability (inflation and currency depreciation); but equations (1) and (2) include these as control variables. And surely one would not argue that a country decides to join the EU because it aims in reducing the size of its FD. This could be seen as a side-effect, but clearly not as the main motivation for EU membership.

Turning on to the data, we use a unique unbalanced panel of monthly observations for all of the (twenty-four) CEECs. ${ }^{9}$ Out of the sample, twelve countries are affiliated to the EU either as member states (Bulgaria, Czech Republic, Estonia, Hungary, Latvia, Lithuania, Poland, Slovak Republic, Slovenia, and Romania) or as candidate countries (Croatia and Turkey). ${ }^{10}$ Data on DD and LD have been jointly collected from the International Financial Statistics of the IMF and from national central bank reports with the sample period varying from one country to the other (the earliest period is 1986:1 (Turkey) and the latest 2010:1 (Albania, Kazakhstan, Moldova)). ${ }^{11}$ This yields a maximum sample size of 4,119 and 3,745 observations for DD and LD respectively, though we end up working with an unbalanced panel of 3,465 and 3,032 observations for equations (1) and (2) respectively due to missing data. Table 1 presents

\footnotetext{
${ }^{7}$ The instrumented variables appear in bold type in the Tables.

${ }^{8} \mathrm{We}$ also subject our dataset to additional regression techniques, the results of which do not appear in the tables as they have no bearing for our findings. These include the fixed-effects, random-effects, standard IV-GMM, and FGLS estimators with an error structure of AR(1). The results of these regressions are available upon request from the author.

${ }^{9}$ Our country sample includes Albania, Armenia, Belarus, Bosnia and Herzegovina, Bulgaria, Croatia, Czech Republic, Estonia, Georgia, Hungary, Kazakhstan, Kyrgyz Republic, Latvia, Lithuania, Macedonia FYR, Moldova, Poland, Romania, Russia, Serbia, Slovak Republic, Slovenia, Turkey, and Ukraine.

${ }^{10}$ Macedonia FYR even though a candidate for EU accession since 2005, as it submitted its membership application in 2004, is not officially a candidate nation as EU accession negotiations have not yet began.

${ }^{11}$ The period coverage of each country appears in the Appendix, Table A3. It is clear that the period for all countries extends well into 2009. Exceptions are the Slovak Republic (2008) and Slovenia (2006) as both have adopted the euro as their legal tender in January of 2009 and January of 2007, respectively. Given that our analysis refers to the pre-euro adoption effects of EU membership on FD, the end of period coverage for these two countries is shorter.
} 
summary statistics of the variables involved in regressions (1) and (2), plus a few additional variables that are used in the sensitivity analysis. What stands out is the extent of both deposit and loan dollarization at an average of $39.64 \%$ and $41.02 \%$ respectively. It is interesting to note, however, that these figures vary widely across countries, with a minimum average DD (LD) of $11.10 \%(11.82 \%)$ in the Czech Republic and a maximum of $69.54 \%$ (70.37\%) in Georgia. Finally, there appears to be a positive correlation between DD and LD of $40.31 \%$.

Figures $1 \mathrm{a}$ and $1 \mathrm{~b}$ show the extent of both types of dollarization in the domestic banking system of the non-EU- and EU-affiliated countries, respectively. Some important characteristics stand out. First, the degree of dollarization exhibits substantial variation across countries. There are countries like Armenia, Bulgaria, Georgia, and the Kyrgyz Rep., that have relatively high levels of both DD and LD, while countries like the Czech Rep. and Slovak Rep. have low levels. Second, for some countries, Albania, Bosnia and Herzegovina, Croatia, Estonia, Macedonia FYR, and Serbia, there is a notable mismatch between the levels of foreign currency deposits and loans. Third, Figure $1 \mathrm{~b}$ illustrates changes in the pattern of both DD and LD for most of the countries that underwent the EU admission process. The vertical lines in each plot identify the beginning of each of the three stages of EU admission giving rise to the prenegotiation period and the (up to three) post-negotiation periods. It appears that for seven of these twelve countries (Bulgaria, Hungary, Latvia, Lithuania, Poland, Slovak Republic, and Slovenia), both the transition toward the EU and joining the EU has been matched with a decrease in DD and a respective increase in LD. The next section investigates these considerations in a more formal way.

\section{Results}

\subsection{Deposit dollarization}

The estimation results of the baseline DD equation (1) appear in Table 2. The seven columns depict our three preferred estimation techniques (FGLS, 2SLS-FE, 2SLS-RE) with different lag structure of the internal instruments for the instrumental variable approaches. All seven regressions confirm the main findings of the literature as these are illustrated by the variables included in the sets $X_{j}$ and $D_{l}$. The highly positive and significant coefficient of the high-dollarization dummy shows that the persistence of DD is higher in highly dollarized countries as depositors in these countries are more sensitive to currency fluctuations and macroeconomic uncertainty (Renhack and Nozaki, 2006; Neanidis and Savva, 2009). The 
degree of legal restrictions on the holdings of foreign currency deposits is also important as it diminishes the size of DD (De Nicoló et al., 2003; Levy-Yeyati, 2006; Honig, 2009). Against the findings first illustrated by Ize and Levy-Yeyati (2003), that the level of DD is increasing with an increase in the mvp share of dollarization, we find that there is no such effect in our sample. We do, however, find support for the currency substitution view as higher inflation causes higher DD. Controlling for inflation, the rate of depreciation is not found to be associated with DD. In line with Arteta (2005), however, the significance of depreciation is reinstated once we drop inflation from the regression, pointing to collinearity between the two variables. ${ }^{12}$

In testing the uncovered interest rate parity, we observe that differences in the rates of interest appear to influence DD only in the FGLS regression with the direction being counter-intuitive. Once we account for its potential endogeneity, with any of the instruments, we find that interest rate spreads have no effect on DD. This finding is consistent with Basso et al. (2007) and Neanidis and Savva (2009), who find interest rate differences to influence the change in DD instead. This is expected as depositors adjust quickly their currency portfolio holdings to changes in interest rate differentials, making them less responsive in the long-run. Finally, higher international financial integration appears to have a positive effect on DD as liberalization of the capital account increases the access of foreign individuals, firms, and banks on domestic banking products, including foreign currency deposits.

Focusing on the effects of the EU-related dummies in the set $E U_{k}$, we observe the strong and robustly negative impact (at the 1\% level) on DD of all three periods that correspond to the EU accession process. The citizens of a country that embarks upon entry negotiations with the EU decrease their foreign currency deposits by 1.6-3 percentage points, depending on the estimation procedure. The negative effects increase in size in the second stage of the process and vary between 5.4-7.5 percentage points, while the effect becomes even larger in the third stage upon admission and vary between 6.9-9.6 percentage points. ${ }^{13}$ The last two rows of Table 2 reports the $p$-values of the Wald tests that examine the statistical equivalence between the EU-related dummies in pairs. The tests show that at each stage of the accession process the size of DD is increasingly diminishing. ${ }^{14}$

\footnotetext{
${ }^{12}$ This, however, has no bearing on the coefficient estimates of the EU-related dummies.

${ }^{13}$ Note that the magnitude of the effects becomes greater and more stable once we control for potential endogeneity of the regressors in columns (2)-(7). The calculated effect in percentage points follows from the fact that the dependent variable is measured on a $[0,1]$ scale, so that the appropriate interpretation in percentage terms requires multiplying the associated coefficient estimates by 100 .

${ }^{14}$ The potential influence of EU membership on FD has also been examined by Neanidis and Savva (2009). Their analysis, which refers to the short-run period (changes in monthly values), does not unveil any significant effects of joining the EU. Their finding, however, is intuitively appealing and does not come into conflict with the finding in the current study as the transition
} 
These figures are non-negligible as the first stage of the accession process is comparable to the impact of the restrictions on foreign currency deposits set by the regulatory arrangements, while the subsequent two stages far exceed this effect. Moreover, the sum of the three EU-related dummies exceeds in statistical significance the effect of the high-dollarization dummy. ${ }^{15}$ The interpretation of these findings is that in the eyes of the private sector EU admission acts as a commitment device for the negotiating country's policymakers that enhances their credibility as to the adoption of policies that promote long-run macroeconomic stability. This, in turn, promotes confidence in the domestic currency and diminishes the holdings of foreign currency deposits. This effect is strengthened as the country passes from one stage of admission to the next and depositors acknowledge the commitment and achievement of their policymakers in following policies that ensure financial stability, in line with the guidelines of the EU.

To establish the robustness of our main findings, we expand the regression equation (1) with additional control variables. These include a measure of trade openness on top of financial openness (Arteta, 2005; Honig, 2009), a dummy variable that measures the extent of alternative hedging opportunities for depositors as captured by the presence of a functional forward market (Arteta, 2005; Luca and Petrova, 2008), a variable that considers the asymmetry of exchange rate movements by constructing an index of bias in exchange rate policy (Renhack and Nozaki, 2006), an index of central bank exchange rate intervention to control for different exchange rate regimes (Barajas and Morales, 2003; Basso et al., 2007), the maximum historical values of inflation and depreciation rates to capture any hysteresis effects (Arteta, 2005), a dummy to control for the immediate aftermath of the Russian crisis (Neanidis and Savva, 2009), and a measure of institutional quality (De Nicoló et al., 2003; Levy-Yeyati, 2006; Honig, 2009).

Table 3 reports the results of the 2SLS-FE estimations, where we add each successive variable as we move to the right of the table. ${ }^{16}$ Let us state from the outset that our findings are insensitive to the change in the specification of the regression equation. If at all, the estimates increase in absolute magnitude as we add more controls. In particular, all columns in Table 3 show that all three dummies that proxy for the EU accession process signify a decline in DD that is always significant at the $1 \%$ level. Consistent with Table 2 , even though we do not report the findings of the Wald tests, the size of the impact rises across the stages of the process. As for the new control variables, in line with Arteta (2005) trade openness encourages DD

process toward EU entry, being a long time period, should not affect the agent's confidence and expectations in the short-run but rather in the long-run.

${ }^{15}$ All these results are supported by Wald tests of linear and non-linear hypotheses used to examine the equality of these (sets of) parameters. They are available upon request.

${ }^{16}$ Our findings are qualitatively similar with the rest of the estimation techniques presented in Table 2. 
as relatively large export and import sectors require foreign currency for their transactions. ${ }^{17}$ Forward market liberalization has no effect on DD, although dropping trade openness as a regressor turns this variable to take up a negative and significant sign. ${ }^{18}$ This is in line with the argument that forward market liberalization allows depositors to insure against currency risk and hedge their exposure in the form of forward contracts. The variable that captures the asymmetry of exchange rate policy, which takes a value of 0 in months of currency appreciation and 1 in months of currency depreciation, suggests the absence of a bias towards currency depreciation identified by Renhack and Nozaki (2006). Its zero impact implies that depositors respond symmetrically to upward and downward changes in the exchange rate toward localcurrency depreciation. As in Basso et al. (2007), the degree of exchange rate intervention by the monetary authorities has no explanatory power in explaining movements in DD.

The next three variables we include, maximum inflation and depreciation rates and a dummy for the Russian crisis, are not significantly related to DD describing the lack of a hysteresis phenomenon and the negligible impact of the Russian crisis on the size of foreign currency deposits. The last column of the table adds the (inverse of the) corruption perception index produced by Transparency International as a means of testing the direct impact of institutional quality on dollarization. Even though its introduction decreases our number of observations by a fourth, it does not affect the coefficient estimates of the EU-related dummies. In addition, as it proxies for the absence of corruption, its negative effect is indicative of the importance attached to higher quality institutions in promoting faith in the domestic currency. Therefore, one can view a country's admission process to the EU as an alternative and complementary way to the improvement of its institutions as both enhance the government's credibility in following policies that promote long-run economic stability. Having discussed the results of Table 3, it is fundamental to note that all these additional findings find strong support in the literature.

\subsection{Loan dollarization}

We now turn to examine the effect of EU membership on the other side of the bank's balance sheet, the dollarization of loans. Table 4 presents the estimates of regression equation (2) with the variety of estimation techniques we have used for equation (1) in Table 2. Columns (1)-(3) estimate a specification

\footnotetext{
${ }^{17}$ Note that the inclusion of trade openness refines the impact of the three EU dummies, compared to column (2) of Table 2, as it increases their magnitude. This supports the notion of competing effects of EU membership on DD that are offsetting each other when trade openness is not controlled for separately. Controlling for openness isolates the institutional quality effects of EU entry and leads to larger negative coefficients.

${ }^{18}$ This is justified by the positive correlation of trade openness and forward market liberalization in our sample.
} 
similar to equation (1) of DD. That is, they do not take into account the potential impact of DD and of the banks' net foreign assets on LD. The results are comparable to the ones outlined in Table 2. As for the case of DD, a highly dollarized country experiences a higher degree of LD, restrictions in the holdings of foreign currency loans limits the extend of LD, the mvp argumentation is once again not relevant in explaining LD, while greater international financial integration boosts LD stressing the borrowers' increased access to foreign funding. In contrast to the findings under DD, we now find that inflation (as opposed to depreciation) is not relevant in explaining LD while depreciation of the local currency leads to higher LD. In addition, a greater wedge between domestic and foreign lending interest rates causes a higher degree of foreign currency borrowing as, ceteris paribus, the cost of borrowing in foreign currency becomes lower. Once again, these results are in line with the findings of the related studies in the literature.

As regards the effects of the EU period dummy variables on LD, we find once again that all three of them are significant. Unlike the case of DD, however, now the effect runs in the opposite direction as they all encourage LD. In addition, the size of their effect is not statistically different across the three stages, as the $p$-values of the Wald tests reveal. Even so, the quantitative size of the effect of each individual stage is still substantial as it coincides with the effect of the regulatory restrictions placed upon foreign currency loans. The explanation of the positive impact of the EU membership process on LD hinges on three factors. First, given that we do not control for trade openness in regressions (1)-(6), EU membership also proxies for greater trade liberalization. As such, greater export and import activities provide hedging opportunities for firms as it makes it easier for them to hedge their foreign currency exposure. Second, due to a growing euro-orientation of exchange rate regimes which derive their credibility from the clause that EU membership will lead to an eventual adoption of the euro. Third, the prospect of monetary integration with the euro area spurs the private sector's confidence in exchange rate stability. As this implies that the risk of an abrupt exchange rate movement is very low, it induces borrowers to increase their foreign currency borrowing. This decline in currency risk is the reason that banks are also more willing to extend loans in foreign currency.

Moving to columns (4)-(6), the innovation corresponds to the inclusion of the level of DD and of the commercial banks' net foreign assets as controls. Even though controlling for these two additional variables bears no qualitative influence on the impact of the remaining regressors, there are some noteworthy quantitative implications. Most importantly, the coefficient estimates of all EU dummies increase in magnitude so that now the Wald tests support the notion of convex effects on LD. As it concerns the effect of the variables themselves, they both confirm the findings of Luca and Petrova (2008) 
and Neanidis and Savva (2009) with regard to the importance of bank related variables as drivers of LD in CEECs. The strong positive effect of DD on LD highlights the banks' desire to maintain matched positions of foreign currency deposits and loans, while the strong negative effect of their net foreign assets indicates their strategy to diversify their assets away from the provision of foreign currency loans.

The final column of Table 4 extends the LD regression with the additional control variables described in Table 3. Foreign currency borrowing is now also affected by trade openness, the functioning of a forward market, the asymmetry of exchange rate policy, historical rates of depreciation, the Russian crisis, and the quality of institutions, all with the expected signs. ${ }^{19}$ Thus, as for the case of DD, institutions exert an independent and complementary effect on LD on top of the effect of the EU membership dummies.

\subsection{Further robustness tests}

We have further subjected our findings to a series of robustness tests. ${ }^{20}$ These tests, that our main results survive, include the modification of the definition of the high-dollarization dummy to take values for ratios above the mean and median, the $40 \%$ level, and the top quartile. We also limit the sample period to the post-1996 years to control for the early abnormal transition years experienced by the participants in the foreign currency market in CEECs as they were more favorable to foreign currency holdings due to the uncertainty that surrounded the success of market-oriented policies. Next, we test whether our findings are a consequence of outlier observations. To this end, we rerun our regressions by dropping a country at each time. We then control separately for the countries in our sample that have experienced high currency mismatches (Albania, Bosnia and Herzegovina, Croatia, Estonia, Macedonia FYR, and Serbia). Finally, we restrict our sample to the EU-affiliated countries. That is, the countries that appear in Figure 1b which are either EU members or candidates for admission. The confirmation of our findings along the line of these tests provides further credibility to our results.

\section{Conclusions}

\footnotetext{
${ }^{19}$ Note that the positive effect of trade openness on LD in column (7) diminishes the respective magnitude of the impact by the EU dummies as compared to column (5). The decline in the effect is larger when we only add trade openness to column (5). This gives support to the thesis offered above as to the first factor that explains the positive impact of EU membership on LD. In other words, once we control for trade openness the EU dummies cease to proxy for this factor anymore.

${ }^{20}$ Although these results are not reported, they are available upon request from the author.
} 
Our aim in this paper has been to study the effect of EU membership on the deposit and loan dollarization of the financial system. The innovation of the paper has been two-fold. First, we used three distinct stages of the transition process toward full EU admission, as defined by the EU, and examined the marginal effect of each stage on both deposit and loan dollarization. Second, we conducted our analysis with the use of a unique panel dataset for 23 CEECs from the early 1990s to the late 2009 .

Our findings suggest that both the prospect of joining the EU - described by the two stages of the commencement of negotiations with the Union and their respective conclusion - and EU membership per se strongly impact upon FD. Deposit dollarization declines during all three stages of the EU admission process, with the effect becoming greater in absolute magnitude as a country surpasses each additional stage. This effect captures the importance the private sector attaches to the negotiation process and ultimately to EU entry as this reflects the commitment of the candidate country's policymakers in following policies that promote macroeconomic and political stability. This process also offers signals of improvement in economic management and institutional development as the country's policies receive external validation by the EU. It is these developments, therefore, that promote confidence in the domestic currency.

Loan dollarization, on the other hand, is found to be continuously increasing during the course of EU negotiations and entry. This result is the outcome of a greater convergence of exchange rates to the euro and the subsequent anticipation for a lower currency risk, the latter diminishing the cost of foreign currency borrowing. These effects are robust to the consideration of indirect channels through which EU membership can boost credit dollarization, such as increased trade openness and liberalization of the capital account.

Overall, our results corroborate the institutional-credibility view of the literature that emphasizes the improvement of government institutions as a way of limiting the degree of deposit dollarization by advancing EU membership as an additional channel through which this can be achieved. At the same time, however, they highlight the diverse impact of some factors on deposit and loan dollarization, notably the EU process of negotiation and entry. These findings advocate the joint consideration of both sides of the bank's balance sheets when it comes to the analysis of financial dollarization. 


\section{References}

Arteta, C.Ó., 2005. Exchange rate regimes and financial dollarization: Does flexibility reduce bank currency mismatches? Topics in Macroeconomics 5(1) Article 10.

Barajas, A., Morales, R.A., 2003. Dollarization of liabilities: Beyond the usual suspects. IMF Working Paper 03/11.

Basso, H.S., Calvo-Gonzalez, O., Jurgilas, M., 2007. Financial dollarization: The role of banks and interest rates. ECB Working Paper 748.

De Nicoló, G., Honohan, P., Ize, A., 2005. Dollarization of the banking system: Causes and consequences. Journal of Banking and Finance 29, 1697-1727.

De Nicoló, G., Honohan, P., Ize, A., 2003. Dollarization of the banking system: Good or bad? IMF Working Paper $03 / 146$

Ecofin, 2000. Council of the European Union press release no. 13055/00.

Genberg, H., 2004. Currency substitution in anticipation of EU accession. In Volbert, A., von Furstenberg, G.M., Mélitz, J., (Eds.), Monetary Unions and Hard Pegs. Oxford Scholarship Online Monographs, Oxford, UK, pp. 337-347.

Honig, A., 2009. Dollarization, exchange rate regimes and government quality. Journal of International Money and Finance 28(2), 198-214.

Honohan, P., 2007. Dollarization and exchange rate fluctuations. CEPR Discussion Paper 6205.

Ize, A., Levy-Yeyati, E., 2003. Financial dollarization. Journal of International Economics 59, 323-347.

Lane, P.R., Milesi-Ferretti, G.M., 2007. The external wealth of nations mark II: Revised and extended estimates of foreign assets and liabilities, 1970-2004. Journal of International Economics 73(2), 223-250.

Levy-Yeyati, E., 2006. Financial dollarization: Evaluating the consequences. Economic Policy 61-118.

Luca, A., Petrova, I., 2008. What drives credit dollarization in transition economies? Journal of Banking and Finance 32(5), 858-869.

Neanidis, K.C., Savva, C.S., 2009. Financial dollarization: Short-run determinants in transition economies. Journal of Banking and Finance 33(10),1860-1873.

Ravenna, F., 2008. The Euro as a commitment device for New European Union Member states. Santa Cruz Center for International Economics Working Paper 04-20.

Rennhack, R., Nozaki, M., 2006. Financial dollarization in Latin America. IMF Working Paper 06/7.

Rosenberg, C.B., Tirpák, M., 2008. Determinants of foreign currency borrowing in the new member states of the EU. IMF Working Paper 08/173.

Savastano, M., 1996. Dollarization in Latin America: Recent evidence and some policy issues. IMF Working Paper $96 / 4$. 
Figure 1a: Financial Dollarization of Non-EU Affiliated Countries
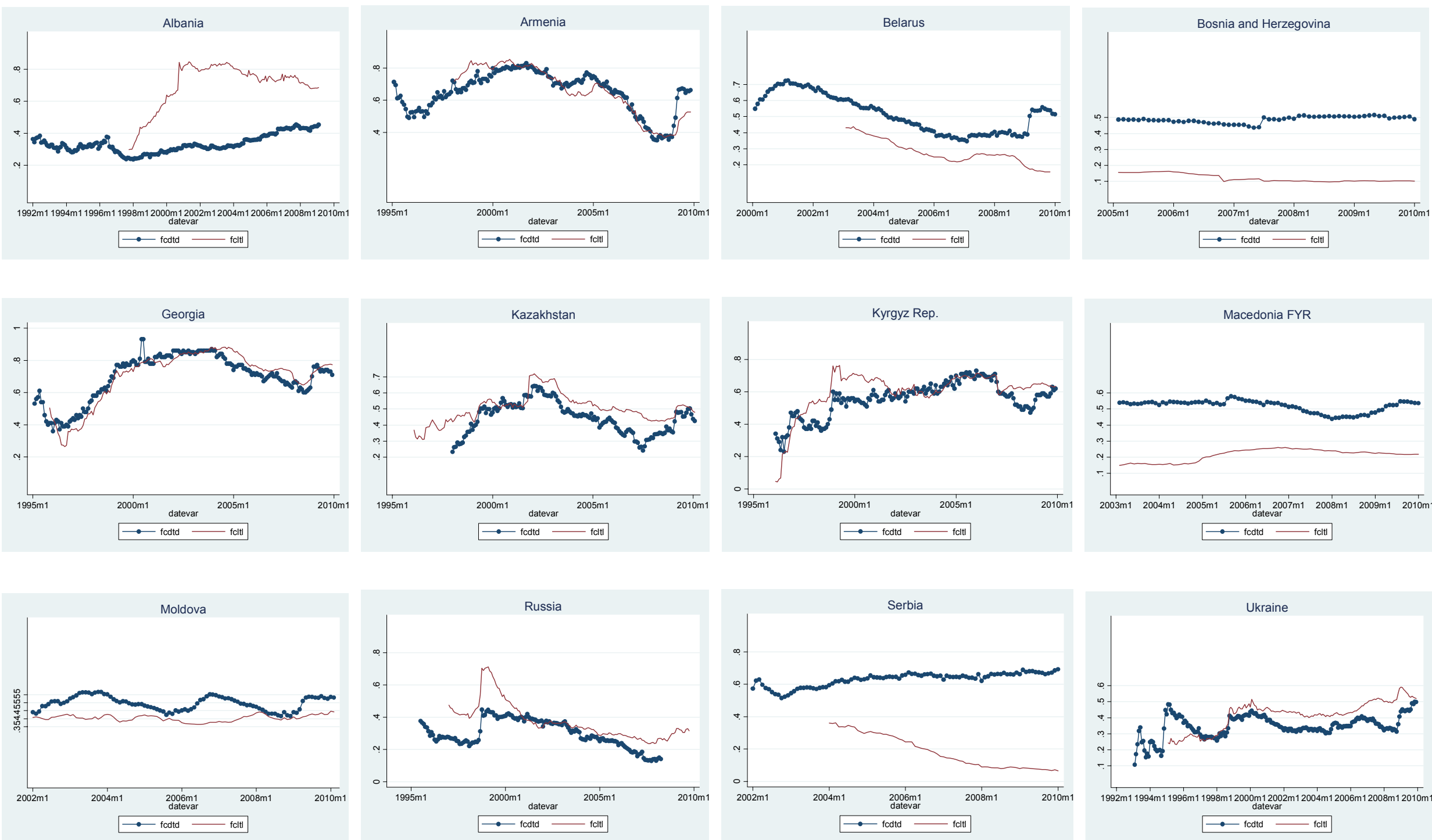
Figure 1b: Financial Dollarization of EU Affiliated Countries
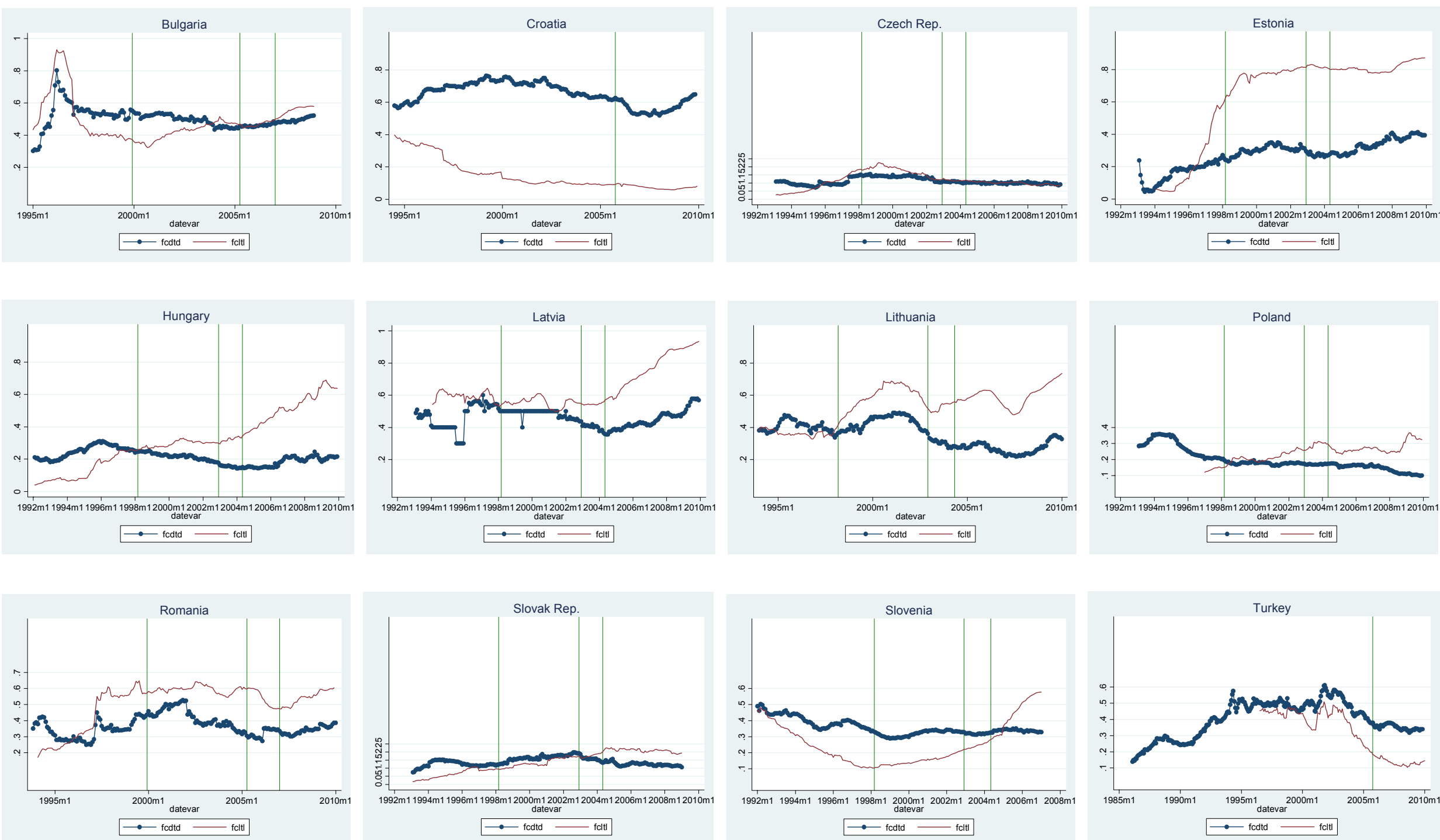
Table 1: Summary Statistics

\begin{tabular}{|c|c|c|c|c|c|}
\hline Variable & Mean & Std Deviation & Min & Max & Obs \\
\hline Deposit dollarization & 39.64 & 18.00 & 4.39 & 93.00 & 4119 \\
\hline Loan dollarization & 41.02 & 23.05 & 1.75 & 93.48 & 3745 \\
\hline High deposit dollarization dummy & 29.82 & 45.75 & 0 & 100 & 4184 \\
\hline High loan dollarization dummy & 42.99 & 49.51 & 0 & 100 & 4184 \\
\hline Net foreign assets & -2.46 & 27.45 & -165.5 & 78.99 & 3970 \\
\hline Restrictions & 0.642 & 0.479 & 0 & 1 & 4039 \\
\hline MVP dollar share & 30.02 & 21.18 & -12.13 & 109 & 4092 \\
\hline Inflation & 1.35 & 4.30 & -5.65 & 123 & 4141 \\
\hline Depreciation & 0.677 & 4.94 & -25.27 & 103.2 & 4118 \\
\hline Interest rate difference (deposits) & 0.101 & 0.271 & -0.296 & 6.77 & 4024 \\
\hline Interest rate difference (loans) & 0.154 & 0.429 & -0.349 & 8.17 & 3791 \\
\hline Index of international financial integration & 1.14 & 0.506 & 0.331 & 3.87 & 3609 \\
\hline Dummy for start of EU accession process & 0.168 & 0.374 & 0 & 1 & 4184 \\
\hline Dummy for decision to join EU & 0.042 & 0.201 & 0 & 1 & 4184 \\
\hline Dummy for European Union membership & 0.134 & 0.341 & 0 & 1 & 4184 \\
\hline Trade openness & 95.28 & 34.19 & 29.41 & 174.4 & 4017 \\
\hline Dummy for forward market liberalization & 0.415 & 0.492 & 0 & 1 & 3907 \\
\hline Index of asymmetry of exchange rate movements & 0.535 & 0.491 & 0 & 1 & 4118 \\
\hline Index of exchange rate intervention & 0.644 & 0.401 & 0 & 1 & 3977 \\
\hline Dummy for maximum inflation rate & 0.006 & 0.075 & 0 & 1 & 4141 \\
\hline Dummy for maximum depreciation rate & 0.006 & 0.076 & 0 & 1 & 4121 \\
\hline Dummy variable for Russian crisis & 0.009 & 0.094 & 0 & 1 & 4182 \\
\hline Corruption perception index & 3.65 & 1.14 & 1.5 & 6.7 & 3131 \\
\hline
\end{tabular}

Sources: See Appendix Table A2. 
Table 2: Deposit Dollarization: Benchmark Model

\begin{tabular}{|c|c|c|c|c|c|c|c|}
\hline Variable & $\begin{array}{c}\text { FGLS } \\
\text { (1) }\end{array}$ & $\begin{array}{c}\text { 2SLS-FE } \\
(2)\end{array}$ & $\begin{array}{c}\text { 2SLS-RE } \\
(3) \\
\end{array}$ & $\begin{array}{c}\text { 2SLS-FE } \\
(4)\end{array}$ & $\begin{array}{c}\text { 2SLS-RE } \\
(5)\end{array}$ & $\begin{array}{c}\text { 2SLS-FE } \\
(6)\end{array}$ & $\begin{array}{c}\text { 2SLS-RE } \\
(7)\end{array}$ \\
\hline \multirow{2}{*}{ High-dollarization dummy } & 0.119 & 0.141 & 0.144 & 0.140 & 0.143 & 0.140 & 0.144 \\
\hline & $(0.000)$ & $(0.000)$ & $(0.000)$ & $(0.000)$ & $(0.000)$ & $(0.000)$ & $(0.000)$ \\
\hline \multirow{2}{*}{ Restrictions on FC deposits } & -0.010 & -0.022 & -0.022 & -0.020 & -0.021 & -0.017 & -0.017 \\
\hline & $(0.000)$ & $(0.000)$ & $(0.000)$ & $(0.000)$ & $(0.000)$ & $(0.001)$ & $(0.000)$ \\
\hline \multirow{2}{*}{ MVP dollar share } & 0.005 & -0.016 & -0.010 & -0.001 & 0.006 & 0.029 & 0.036 \\
\hline & $(0.617)$ & $(0.204)$ & $(0.434)$ & $(0.985)$ & $(0.712)$ & $(0.210)$ & $(0.110)$ \\
\hline \multirow[t]{2}{*}{ Inflation } & 0.182 & 0.321 & 0.319 & 0.709 & 0.706 & 1.33 & 1.32 \\
\hline & $(0.000)$ & $(0.001)$ & $(0.001)$ & $(0.000)$ & $(0.000)$ & $(0.000)$ & $(0.000)$ \\
\hline \multirow[t]{2}{*}{ Depreciation } & 0.024 & 0.047 & 0.047 & -0.117 & -0.114 & -0.804 & -0.787 \\
\hline & $(0.270)$ & $(0.646)$ & $(0.647)$ & $(0.724)$ & $(0.733)$ & $(0.143)$ & $(0.153)$ \\
\hline \multirow{2}{*}{ Interest rate difference } & 0.024 & 0.009 & 0.009 & -0.001 & -0.002 & 0.014 & 0.012 \\
\hline & $(0.000)$ & $(0.229)$ & $(0.257)$ & $(0.930)$ & $(0.901)$ & $(0.693)$ & $(0.741)$ \\
\hline \multirow{2}{*}{ International financial integration } & 0.052 & 0.062 & 0.062 & 0.062 & 0.063 & 0.058 & 0.059 \\
\hline & $(0.000)$ & $(0.000)$ & $(0.000)$ & $(0.000)$ & $(0.000)$ & $(0.000)$ & $(0.000)$ \\
\hline \multirow[t]{2}{*}{ Start of EU accession process } & -0.016 & -0.029 & -0.030 & -0.026 & -0.027 & -0.022 & -0.024 \\
\hline & $(0.000)$ & $(0.000)$ & $(0.000)$ & $(0.000)$ & $(0.000)$ & $(0.000)$ & $(0.000)$ \\
\hline \multirow{2}{*}{ Decision to join EU } & -0.054 & -0.074 & -0.075 & -0.071 & -0.072 & -0.069 & -0.070 \\
\hline & $(0.000)$ & $(0.000)$ & $(0.000)$ & $(0.000)$ & $(0.000)$ & $(0.000)$ & $(0.000)$ \\
\hline \multirow{2}{*}{ EU membership } & -0.069 & -0.096 & -0.096 & -0.093 & -0.094 & -0.088 & -0.089 \\
\hline & $(0.000)$ & $(0.000)$ & $(0.000)$ & $(0.000)$ & $(0.000)$ & $(0.000)$ & $(0.000)$ \\
\hline Countries / Obs & $24 / 3465$ & $24 / 3443$ & $24 / 3443$ & $24 / 3421$ & $24 / 3421$ & $24 / 3399$ & $24 / 3399$ \\
\hline R-square (adjusted) & & 0.675 & 0.686 & 0.694 & 0.705 & 0.739 & 0.747 \\
\hline Lag structure of internal instruments & & One lag & One lag & Two lags & Two lags & Three lags & Three lags \\
\hline Wald test of start EU $=$ decision EU & 0.000 & 0.000 & 0.000 & 0.000 & 0.000 & 0.000 & 0.000 \\
\hline Wald test of decision $\mathrm{EU}=$ join $\mathrm{EU}$ & 0.000 & 0.000 & 0.000 & 0.000 & 0.000 & 0.006 & 0.006 \\
\hline
\end{tabular}

Notes: Dependent variable is deposit dollarization. p-values in parentheses based on robust standard errors for the 2SLS-FE and 2SLS-RE estimators and adjusted for panel heteroskedasticity for the FGLS estimator that controls for country fixed effects. Constant term not reported. Instrumented variables are in bold type. Instruments are the once lagged values of the endogenous variables in columns (2) and (3), the twice lagged values in columns (4) and (5), and the third lagged values in columns (6) and (7). Even though not reported, results are the same when using as instruments any combinations of the first to third lagged values. Findings are also qualitatively similar for the variables of interest with Fixed-Effects, Random-Effects, GMM, and FGLS estimators with an error structure of AR(1). The Wald tests present the p-values of the simple linear hypotheses about the equality of the EU-related parameters in pairs. 
Table 3: Deposit Dollarization: Extended Model

\begin{tabular}{|c|c|c|c|c|c|c|c|c|}
\hline Variable & $\begin{array}{l}\text { 2SLS-FE } \\
\text { (1) }\end{array}$ & $\begin{array}{l}\text { 2SLS-FE } \\
(2)\end{array}$ & $\begin{array}{c}\text { 2SLS-FE } \\
(3) \\
\end{array}$ & $\begin{array}{l}\text { 2SLS-FE } \\
(4)\end{array}$ & $\begin{array}{c}\text { 2SLS-FE } \\
(5)\end{array}$ & $\begin{array}{c}\text { 2SLS-FE } \\
(6)\end{array}$ & $\begin{array}{c}\text { 2SLS-FE } \\
(7)\end{array}$ & $\begin{array}{c}\text { 2SLS-FE } \\
(8) \\
\end{array}$ \\
\hline \multirow{2}{*}{ High-dollarization dummy } & 0.138 & 0.138 & 0.138 & 0.131 & 0.131 & 0.131 & 0.131 & 0.111 \\
\hline & $(0.000)$ & $(0.000)$ & $(0.000)$ & $(0.000)$ & $(0.000)$ & $(0.000)$ & $(0.000)$ & $(0.000)$ \\
\hline \multirow{2}{*}{ Restrictions on FC deposits } & -0.014 & -0.014 & -0.014 & -0.019 & -0.019 & -0.019 & -0.019 & -0.008 \\
\hline & $(0.000)$ & $(0.000)$ & $(0.000)$ & $(0.000)$ & $(0.000)$ & $(0.000)$ & $(0.000)$ & $(0.074)$ \\
\hline \multirow[t]{2}{*}{ MVP dollar share } & -0.001 & -0.001 & -0.001 & -0.002 & -0.003 & -0.003 & -0.003 & 0.172 \\
\hline & $(0.947)$ & $(0.910)$ & $(0.882)$ & $(0.835)$ & $(0.810)$ & $(0.805)$ & $(0.806)$ & $(0.000)$ \\
\hline \multirow[t]{2}{*}{ Inflation } & 0.305 & 0.305 & 0.307 & 0.382 & 0.398 & 0.397 & 0.397 & -0.042 \\
\hline & $(0.001)$ & $(0.001)$ & $(0.001)$ & $(0.000)$ & $(0.000)$ & $(0.000)$ & $(0.000)$ & $(0.879)$ \\
\hline \multirow{2}{*}{ Depreciation } & 0.088 & 0.087 & 0.080 & -0.018 & -0.013 & -0.014 & -0.014 & 1.25 \\
\hline & $(0.389)$ & $(0.397)$ & $(0.480)$ & $(0.868)$ & $(0.902)$ & $(0.906)$ & $(0.908)$ & $(0.000)$ \\
\hline \multirow{2}{*}{ Interest rate difference } & 0.011 & 0.011 & 0.010 & -0.003 & -0.004 & -0.004 & -0.004 & 0.015 \\
\hline & $(\mathbf{0 . 1 5 5 )}$ & $(0.165)$ & (0.173) & $(0.658)$ & $(0.603)$ & $(0.617)$ & $(0.617)$ & $(0.421)$ \\
\hline \multirow[t]{2}{*}{ International financial integration } & 0.054 & 0.054 & 0.054 & 0.052 & 0.051 & 0.051 & 0.051 & 0.018 \\
\hline & $(\mathbf{0 . 0 0 0 )}$ & $(\mathbf{0 . 0 0 0 )}$ & $(0.000)$ & $(0.000)$ & $(0.000)$ & $(0.000)$ & $(0.000)$ & $(0.000)$ \\
\hline \multirow{2}{*}{ Start of EU accession process } & -0.034 & -0.034 & -0.034 & -0.032 & -0.032 & -0.032 & -0.032 & -0.056 \\
\hline & $(0.000)$ & $(0.000)$ & $(0.000)$ & $(0.000)$ & $(0.000)$ & $(0.000)$ & $(0.000)$ & $(0.000)$ \\
\hline \multirow{2}{*}{ Decision to join EU } & -0.081 & -0.081 & -0.081 & -0.082 & -0.082 & -0.083 & -0.083 & -0.094 \\
\hline & $(0.000)$ & $(0.000)$ & $(0.000)$ & $(0.000)$ & $(0.000)$ & $(0.000)$ & $(0.000)$ & $(0.000)$ \\
\hline \multirow{2}{*}{ EU membership } & -0.111 & -0.110 & -0.111 & -0.109 & -0.109 & -0.109 & -0.109 & -0.105 \\
\hline & $(0.000)$ & $(0.000)$ & $(0.000)$ & $(0.000)$ & $(0.000)$ & $(0.000)$ & $(0.000)$ & $(0.000)$ \\
\hline \multirow[t]{2}{*}{ Trade openness } & 0.090 & 0.090 & 0.090 & 0.077 & 0.077 & 0.077 & 0.077 & 0.132 \\
\hline & $(0.000)$ & $(0.000)$ & $(0.000)$ & $(0.000)$ & $(0.000)$ & $(0.000)$ & $(0.000)$ & $(0.000)$ \\
\hline \multirow{2}{*}{ Forward market liberalization } & & -0.001 & -0.001 & 0.006 & 0.006 & 0.006 & 0.006 & 0.016 \\
\hline & & $(0.793)$ & $(0.876)$ & $(0.183)$ & $(0.175)$ & $(0.175)$ & $(0.176)$ & $(0.003)$ \\
\hline \multirow{2}{*}{ Asymmetry } & & & 0.003 & 0.006 & 0.006 & 0.006 & 0.006 & -0.041 \\
\hline & & & $(0.554)$ & $(0.190)$ & $(0.212)$ & $(0.248)$ & $(0.252)$ & $(0.002)$ \\
\hline \multirow[t]{2}{*}{ Intervention } & & & & 0.003 & 0.003 & 0.003 & 0.003 & 0.001 \\
\hline & & & & $(0.302)$ & $(0.292)$ & $(0.290)$ & $(0.290)$ & $(0.866)$ \\
\hline \multirow[t]{2}{*}{ Max inflation rate } & & & & & -0.031 & -0.031 & -0.031 & -0.010 \\
\hline & & & & & $(0.055)$ & $(0.054)$ & $(0.055)$ & $(0.686)$ \\
\hline \multirow[t]{2}{*}{ Max depreciation rate } & & & & & & 0.003 & 0.003 & -0.393 \\
\hline & & & & & & $(0.944)$ & $(0.945)$ & $(0.000)$ \\
\hline \multirow[t]{2}{*}{ Russian crisis } & & & & & & & -0.001 & -0.045 \\
\hline & & & & & & & $(0.987)$ & $(0.008)$ \\
\hline \multirow[t]{2}{*}{ Corruption } & & & & & & & & -0.019 \\
\hline & & & & & & & & $(0.000)$ \\
\hline Countries / Obs & $24 / 3443$ & $24 / 3443$ & $24 / 3443$ & $24 / 3443$ & $24 / 3443$ & $24 / 3443$ & $24 / 3443$ & $24 / 2545$ \\
\hline R-square (adjusted) & 0.540 & 0.542 & 0.538 & 0.535 & 0.536 & 0.536 & 0.536 & 0.583 \\
\hline
\end{tabular}


Table 4: Loan Dollarization: Benchmark and Extended Model

\begin{tabular}{|c|c|c|c|c|c|c|c|}
\hline Variable & $\begin{array}{c}\text { FGLS } \\
(1)\end{array}$ & $\begin{array}{c}\text { 2SLS-FE } \\
(2)\end{array}$ & $\begin{array}{c}\text { 2SLS-RE } \\
(3) \\
\end{array}$ & $\begin{array}{c}\text { FGLS } \\
(4)\end{array}$ & $\begin{array}{c}\text { 2SLS-FE } \\
(5) \\
\end{array}$ & $\begin{array}{c}\text { 2SLS-RE } \\
(6) \\
\end{array}$ & $\begin{array}{c}\text { 2SLS-FE } \\
(7)\end{array}$ \\
\hline High-dollarization dummy & $\begin{array}{c}0.217 \\
(0.000)\end{array}$ & $\begin{array}{c}0.228 \\
(0.000)\end{array}$ & $\begin{array}{c}0.237 \\
(0.000)\end{array}$ & $\begin{array}{c}0.149 \\
(0.000)\end{array}$ & $\begin{array}{c}0.154 \\
(0.000)\end{array}$ & $\begin{array}{c}0.165 \\
(0.000)\end{array}$ & $\begin{array}{c}0.111 \\
(0.000)\end{array}$ \\
\hline Restrictions on FC loans & $\begin{array}{l}-0.044 \\
(0.000)\end{array}$ & $\begin{array}{l}-0.039 \\
(0.000)\end{array}$ & $\begin{array}{c}-0.042 \\
(0.000)\end{array}$ & $\begin{array}{l}-0.024 \\
(0.000)\end{array}$ & $\begin{array}{l}-0.019 \\
(0.000)\end{array}$ & $\begin{array}{l}-0.022 \\
(0.000)\end{array}$ & $\begin{array}{l}-0.023 \\
(0.000)\end{array}$ \\
\hline MVP dollar share & $\begin{array}{l}-0.014 \\
(0.153)\end{array}$ & $\begin{array}{l}-0.014 \\
(0.444)\end{array}$ & $\begin{array}{c}0.020 \\
(0.268)\end{array}$ & $\begin{array}{l}-0.019 \\
(0.054)\end{array}$ & $\begin{array}{l}-0.019 \\
(0.242)\end{array}$ & $\begin{array}{c}0.007 \\
(0.657)\end{array}$ & $\begin{array}{c}0.023 \\
(0.250)\end{array}$ \\
\hline Inflation & $\begin{array}{l}-0.042 \\
(0.464)\end{array}$ & $\begin{array}{c}-0.228 \\
(0.240)\end{array}$ & $\begin{array}{l}-0.237 \\
(0.225)\end{array}$ & $\begin{array}{l}-0.201 \\
(0.000)\end{array}$ & $\begin{array}{l}-0.347 \\
(0.039)\end{array}$ & $\begin{array}{l}-0.341 \\
(0.046)\end{array}$ & $\begin{array}{l}-0.252 \\
(0.393)\end{array}$ \\
\hline Depreciation & $\begin{array}{c}0.123 \\
(0.000)\end{array}$ & $\begin{array}{c}0.758 \\
(0.000)\end{array}$ & $\begin{array}{c}0.750 \\
(0.000)\end{array}$ & $\begin{array}{c}0.155 \\
(0.000)\end{array}$ & $\begin{array}{c}0.759 \\
(0.000)\end{array}$ & $\begin{array}{c}0.748 \\
(0.000)\end{array}$ & $\begin{array}{c}1.31 \\
(0.000)\end{array}$ \\
\hline Interest rate difference & $\begin{array}{c}0.032 \\
(0.000)\end{array}$ & $\begin{array}{c}0.030 \\
(0.003)\end{array}$ & $\begin{array}{c}0.030 \\
(0.003)\end{array}$ & $\begin{array}{c}0.042 \\
(0.000)\end{array}$ & $\begin{array}{c}0.031 \\
(0.000)\end{array}$ & $\begin{array}{c}0.032 \\
(0.000)\end{array}$ & $\begin{array}{c}0.138 \\
(0.000)\end{array}$ \\
\hline International financial integration & $\begin{array}{c}0.065 \\
(0.000)\end{array}$ & $\begin{array}{c}0.075 \\
(0.000)\end{array}$ & $\begin{array}{c}0.073 \\
(0.000)\end{array}$ & $\begin{array}{c}0.044 \\
(0.000)\end{array}$ & $\begin{array}{c}0.047 \\
(0.000)\end{array}$ & $\begin{array}{c}0.044 \\
(0.000)\end{array}$ & $\begin{array}{c}0.026 \\
(0.000)\end{array}$ \\
\hline Start of EU accession process & $\begin{array}{c}0.031 \\
(0.000)\end{array}$ & $\begin{array}{c}0.028 \\
(0.000)\end{array}$ & $\begin{array}{c}0.025 \\
(0.000)\end{array}$ & $\begin{array}{c}0.034 \\
(0.000)\end{array}$ & $\begin{array}{c}0.046 \\
(0.000)\end{array}$ & $\begin{array}{c}0.044 \\
(0.000)\end{array}$ & $\begin{array}{c}0.046 \\
(0.000)\end{array}$ \\
\hline Decision to join EU & $\begin{array}{c}0.033 \\
(0.000)\end{array}$ & $\begin{array}{c}0.036 \\
(0.000)\end{array}$ & $\begin{array}{c}0.034 \\
(0.000)\end{array}$ & $\begin{array}{c}0.057 \\
(0.000)\end{array}$ & $\begin{array}{c}0.081 \\
(0.000)\end{array}$ & $\begin{array}{c}0.080 \\
(0.000)\end{array}$ & $\begin{array}{c}0.069 \\
(0.000)\end{array}$ \\
\hline EU membership & $\begin{array}{c}0.046 \\
(0.000)\end{array}$ & $\begin{array}{c}0.047 \\
(0.000)\end{array}$ & $\begin{array}{c}0.047 \\
(0.000)\end{array}$ & $\begin{array}{c}0.068 \\
(0.000)\end{array}$ & $\begin{array}{c}0.091 \\
(0.000)\end{array}$ & $\begin{array}{c}0.092 \\
(0.000)\end{array}$ & $\begin{array}{c}0.084 \\
(0.000)\end{array}$ \\
\hline Deposit dollarization & & & & $\begin{array}{c}0.651 \\
(0.000)\end{array}$ & $\begin{array}{c}0.696 \\
(0.000)\end{array}$ & $\begin{array}{c}0.656 \\
(0.000)\end{array}$ & $\begin{array}{c}0.587 \\
(0.000)\end{array}$ \\
\hline Net foreign assets & & & & $\begin{array}{l}-0.105 \\
(0.000)\end{array}$ & $\begin{array}{c}-0.108 \\
(0.000)\end{array}$ & $\begin{array}{l}-0.105 \\
(0.000)\end{array}$ & $\begin{array}{l}-0.105 \\
(0.000)\end{array}$ \\
\hline Trade openness & & & & & & & $\begin{array}{c}0.113 \\
(0.000)\end{array}$ \\
\hline Forward market liberalization & & & & & & & $\begin{array}{c}0.012 \\
(0.044)\end{array}$ \\
\hline Asymmetry & & & & & & & $\begin{array}{l}-0.041 \\
(0.003)\end{array}$ \\
\hline Intervention & & & & & & & $\begin{array}{l}-0.006 \\
(0.172)\end{array}$ \\
\hline Max inflation rate & & & & & & & $\begin{array}{c}0.004 \\
(0.868)\end{array}$ \\
\hline Max depreciation rate & & & & & & & $\begin{array}{l}-0.390 \\
(0.002)\end{array}$ \\
\hline Russian crisis & & & & & & & $\begin{array}{c}-0.051 \\
(0.009)\end{array}$ \\
\hline Corruption & & & & & & & $\begin{array}{l}-0.015 \\
(0.000) \\
\end{array}$ \\
\hline Countries / Obs & $23 / 3032$ & $23 / 3016$ & $23 / 3016$ & $23 / 2997$ & $23 / 2979$ & $23 / 2979$ & $23 / 2312$ \\
\hline R-square (adjusted) & & 0.658 & 0.703 & & 0.670 & 0.674 & 0.482 \\
\hline Wald test of start EU $=$ decision $E U$ & 0.564 & 0.262 & 0.180 & 0.000 & 0.000 & 0.000 & 0.000 \\
\hline Wald test of decision $\mathrm{EU}=$ join $\mathrm{EU}$ & 0.003 & 0.157 & 0.118 & 0.009 & 0.120 & 0.071 & 0.009 \\
\hline
\end{tabular}




\section{APPENDIX}

\section{Table A1: EU Accession Process Dates}

\begin{tabular}{cccl}
\hline Beginning of negotiations & End of negotiations & Full membership & \multicolumn{1}{c}{ Country } \\
\hline March of 1998 & December of 2002 & May of 2004 & Czech Rep., Estonia, \\
& & Hungary, Latvia, \\
& & Lithuania, Poland, \\
& & Slovak Rep., and \\
December of 1999 & April of 2005 & January of 2007 & Slovenia \\
October of 2005 & & Bulgaria and Romania \\
\hline
\end{tabular}

Notes: Macedonia FYR does not appear in the table. Even though a candidate for EU accession since 2005, as it submitted its membership application in 2004, EU accession negotiations have not yet began. 
Table A2: Variable Definitions and Sources

\begin{tabular}{|c|c|}
\hline Variable & Definition [source] \\
\hline \multicolumn{2}{|l|}{ Dependent variables } \\
\hline Deposit dollarization & $\begin{array}{l}\text { Foreign currency denominated deposits to total deposits of residents held in resident } \\
\text { banks [IMF, International Financial Statistics (IFS) and National Central Banks (NCB)] }\end{array}$ \\
\hline Loan dollarization & $\begin{array}{l}\text { Foreign currency denominated credit to total credits of residents issued by resident } \\
\text { banks [IFS and NCB] }\end{array}$ \\
\hline \multicolumn{2}{|l|}{ Independent variables } \\
\hline Net foreign assets & $\begin{array}{l}\text { The ratio of commercial banks' and other depository corporations' foreign assets minus } \\
\text { external liabilities to total domestic deposits [IFS and NCB] }\end{array}$ \\
\hline $\begin{array}{l}\text { Restrictions on FC deposits } \\
\text { (loans) }\end{array}$ & $\begin{array}{l}\text { Dummy variable that takes the value of } 1 \text { when there are restrictions on residents } \\
\text { holdings of onshore foreign currency deposits (loans) and } 0 \text { otherwise [AREAR, IMF] }\end{array}$ \\
\hline MVP dollar share & $\begin{array}{l}{[\operatorname{Var}(\text { Inflation })+\operatorname{Cov}(\text { Inflation, } \Delta(\text { Real exchange rate) })] /[\operatorname{Var}(\text { Inflation })+\operatorname{Var}(\Delta} \\
(\text { Real exchange rate) })+2 \operatorname{Cov}(\text { Inflation, } \Delta(\text { Real exchange rate) })] \text { as constructed by Ize } \\
\text { and Levy-Yeyati }(2003) \text {. Following Basso et al. }(2007) \text {, we compute MVP based on all } \\
\text { historical information up to the observation point. [Author's calculation] }\end{array}$ \\
\hline Inflation & Logarithmic difference of the Consumer Price Index [IFS] \\
\hline Depreciation & $\begin{array}{l}\text { Logarithmic difference of the nominal official exchange rate (national currency/USD) } \\
\text { [IFS] }\end{array}$ \\
\hline Interest rate difference & $\begin{array}{l}\text { Deposit and loan interest rate differences (local currency - foreign currency)/100 [IFS } \\
\text { and NCB]. No data availability of loan interest rates for Turkey. }\end{array}$ \\
\hline $\begin{array}{l}\text { International financial } \\
\text { integration }\end{array}$ & $\begin{array}{l}\text { Volume-based measure of international financial integration as constructed by Lane and } \\
\text { Milesi-Ferretti (2007): (total external assets + total external liabilities) / GDP [updated } \\
\text { and extended version of the External Wealth of Nations Mark II database developed by } \\
\text { Lane and Milesi-Ferretti (2007)] }\end{array}$ \\
\hline $\begin{array}{l}\text { Start of EU accession } \\
\text { process }\end{array}$ & $\begin{array}{l}\text { Dummy variable that takes the value of } 1 \text { during the dates of the beginning of the EU } \\
\text { accession negotiations and before the end of the negotiation process and } 0 \text { otherwise } \\
\text { [http://europa.eu/abc/history]. See Table A3 below for details. }\end{array}$ \\
\hline Decision to join EU & $\begin{array}{l}\text { Dummy variable that takes the value of } 1 \text { during the dates decided by the EU for } \\
\text { negotiating countries to join the EU and before full EU membership and } 0 \text { otherwise } \\
\text { [http://europa.eu/abc/history]. See Table A3 below for details. }\end{array}$ \\
\hline EU membership & $\begin{array}{l}\text { Dummy variable that takes the value of } 1 \text { after full membership to the EU and } 0 \\
\text { otherwise [http://europa.eu/abc/history]. See Table A3 below for details. }\end{array}$ \\
\hline Trade openness & The ratio of trade to GDP [WDI] \\
\hline Forward market & Dummy variable that takes the value of 1 if there exists a functional forward market and \\
\hline liberalization & 0 otherwise [Luca and Petrova (2007) and AREAR, IMF] \\
\hline Asymmetry & $\begin{array}{l}\text { Index of asymmetry of exchange rate movements as constructed by Rennhack and } \\
\text { Nozaki (2006): assigning a value of } 0 \text { in months of currency appreciation and } 1 \text { in } \\
\text { months of currency depreciation [Author's calculation] }\end{array}$ \\
\hline Intervention & $\begin{array}{l}\text { Indicator of exchange rate intervention as constructed by Barajas and Morales }(2003): \\
(\Delta \text { int_res/M2 })^{2} /\left((\text { First Difference(Exchange Rate) } / \text { Exchange Rate })^{2}+(\Delta \text { int_res/M2 })^{2}\right) \\
{[\text { Author's calculation drawn from IFS] }}\end{array}$ \\
\hline Max inflation rate & Maximum value of inflation rate [IFS] \\
\hline Max depreciation rate & Maximum value of change in the exchange rate [IFS] \\
\hline Russian crisis & $\begin{array}{l}\text { Dummy variable that takes the value of } 1 \text { during August-December } 1998 \text { and } 0 \\
\text { otherwise. }\end{array}$ \\
\hline Corruption & Inverse of corruption perception index [Transparency International] \\
\hline
\end{tabular}


Table A3: Country Coverage and Dollarization Data Availability

\begin{tabular}{|c|c|c|c|c|}
\hline Country & Deposits & Observations & Loans & Observations \\
\hline Albania & 1992:12-2010:1 & 206 & 1998:9-2010:1 & 137 \\
\hline Armenia & 1995:1-2009:10 & 178 & 1998:1-2009:10 & 142 \\
\hline Belarus & 2000:1-2009:10 & 118 & 2003:1-2009:10 & 82 \\
\hline Bosnia and Herzegovina & 2005:1-2009:12 & 60 & 2005:1-2009:12 & 60 \\
\hline Bulgaria & $1995: 12-2009: 11$ & 167 & $1995: 12-2009: 11$ & 167 \\
\hline Croatia & 1994:6-2009:10 & 185 & 1994:6-2009:11 & 186 \\
\hline Czech Rep. & 1993:1-2009:11 & 203 & 1993:1-2009:11 & 203 \\
\hline Estonia & 1993:1-2009:11 & 203 & 1993:1-2009:11 & 203 \\
\hline Georgia & 1995:1-2009:11 & 179 & 1995:10-2009:11 & 170 \\
\hline Hungary & 1992:1-2009:11 & 215 & 1992:1-2009:11 & 215 \\
\hline Kazakhstan & 1997:12-2010:1 & 146 & 1996:1-2010:1 & 169 \\
\hline Kyrgyz Rep. & 1996:1-2009:11 & 167 & 1996:1-2009:11 & 167 \\
\hline Latvia & 1993:1-2009:11 & 203 & 1994:1-2009:11 & 191 \\
\hline Lithuania & $1993: 12-2009: 12$ & 193 & 1993:12-2009:12 & 193 \\
\hline Macedonia FYR & 2003:1-2009:12 & 84 & 2003:1-2009:12 & 84 \\
\hline Moldova & 2001:12-2010:1 & 98 & 2001:12-2010:1 & 98 \\
\hline Poland & 1993:1-2009:11 & 203 & $1996: 12-2009: 11$ & 156 \\
\hline Romania & 1993:9-2009:11 & 195 & 1993:12-2009:11 & 192 \\
\hline Russia & $1995: 6-2008: 3$ & 154 & 1996:12-2009:9 & 154 \\
\hline Serbia & 2001:12-2009:12 & 97 & 2003:12-2009:12 & 73 \\
\hline Slovak Rep. & 1993:1-2008:12 & 192 & 1993:1-2008:12 & 192 \\
\hline Slovenia & $1991: 12-2006: 12$ & 181 & $1991: 12-2006: 12$ & 181 \\
\hline Turkey & 1986:1-2009:10 & 286 & 1996:6-2009:11 & 163 \\
\hline Ukraine & 1993:1-2009:11 & 203 & 1995:1-2009:11 & 179 \\
\hline
\end{tabular}

Notes: The data coverage of the EU affiliated countries (members and candidates) appears in Italics. The end of the coverage period is shorter for the Slovak Republic and Slovenia as both have adopted the euro as their legal tender in January of 2009 and January of 2007 respectively. 